\title{
The effect of derivatives of sulfur-containing amino acids (ademetionine, taurine and glutathione) on survival of animals with acute kidney injury of various genesis
}

Aim. To study the nephroprotective effect of sulfur-containing amino acids (ademetionine, taurine and glutathione) on different models of acute kidney injury (AKI) by the integral index of the survival rate of animals.

Materials and methods. The experiments were performed on 105 non-linear mature white laboratory rats and 35 mice. The drugs studied - ademetionine (Geptral, Abbott SpA, Italy) in the dose of $20 \mathrm{mg} / \mathrm{kg}$, glutathione (TAD 600, Biomedica Foscama, Italy) in the dose of $30 \mathrm{mg} / \mathrm{kg}$ and taurine (Sigma-Aldrich, USA) in the dose of dose $100 \mathrm{mg} / \mathrm{kg}-$ were injected intraperitoneally 3-7 days before AKI modeling. Rhabdomyolysis-induced AKI was modeled by the intramuscular injection of $50 \%$ glycerol solution in the dose of $10 \mathrm{ml} / \mathrm{kg}$, toxic AKI - by the injection of gentamicin solution in the dose of $80 \mathrm{mg} / \mathrm{kg}$ and the subcutaneous injection of ethylene glycol in the dose of $10 \mathrm{ml} / \mathrm{kg}$. Simulation of renal ischemia was performed under general anesthesia (ethaminal sodium, $40 \mathrm{mg} / \mathrm{kg}$ ) by clamping of both renal pedicles for a period of $60 \mathrm{~min}$, followed by reperfusion for $24 \mathrm{~h}$.

Results and discusion. The experimental results show a significant improvement in the survival of animals under the effect of the drugs of derivatives of sulfur-containing amino acids studied in conditions of various models of AKI. Ademetionine, taurine and glutathione reduced the lethality of animals on models of rhabdomyolytic, gentamicin, ischemia-reperfusion AKI. In conditions of ethylene glycol intoxication the highest nephroprotective activity by the survival criterion was shown by glutathione $(57.1 \%$ survival at $48 \mathrm{~h}$ after administration of ethylene glycol against $100 \%$ of mortality in the control group ( $p<0.05)$.

Conclusions. All derivatives of sulfur-containing amino acids studied (ademetionine, taurine and glutathione) exhibit the nephroprotective activity by the criterion of survival of animals on various models of AKI. Glutathione demonstrates the best survival of animals with acute kidney injury of various genesis, while ademetionine has the lowest survival.

Key words: nephroprotection; acute kidney injury; survival; ademetionine; taurine; glutathione

В. М. Драчук, І. І. Заморський, Т. С. Щудрова, О. М. Горошко

Вплив препаратів похідних сірковмісних амінокислот (адеметіоніну, таурину та глутатіону) на виживаність тварин при гострому пошкодженні нирок різного ґенезу

Мета роботи - дослідити нефропротекторну активність похідних сірковмісних амінокислот (адеметіоніну, таурину та глутатіону) на різних моделях гострого пошкодження нирок (ГПН) за інтегральним показником виживаності тварин.

Матеріали та методи. Дослідження проводились на 105 нелінійних зрілих білих лабораторних щурах і 35 мишах. Досліджувані препарати: адеметіонін - («Гептрал», Abbott SpA, Італія) в дозі 20 мг/кг, препарат глутатіону («ТАД 600», Biomedica Foscama, Італія) в дозі 30 мг/кг і таурин («Sigma-Aldrich», США) в дозі 100 мг/кг вводили внутрішньоочеревинно за 3-7 днів до моделювання гострого пошкодження нирок. Рабдоміоліз-індуковане ГПН моделювали внутрішньом'язовою ін'єкцією 50 \% розчину гліцеролу в дозі 10 мл/кг, токсично-індуковане ГПН - шляхом одноразової внутрішньом'язової ін'єкції розчину гентаміцину сульфрату в дозі 80 мг/кг або одноразового підшкірного введення мишам етиленгліколю дозою 10 мл/кг. Ішемічне пошкодження нирок моделювали під загальною анестезією (етамінал-натрію, 40 мг/кг), наклавши затискачі на обидві ниркові ніжки на період 60 хв 3 подальшою реперфузією впродовж 24 годин.

Результати та їх обговорення. За результатами серій експериментів з визначення впливу досліджуваних препаратів похідних сірковмісних амінокислот на перебіг різних моделей гострого пошкодження нирок різного ґенезу встановлено значне покращення виживаності тварин. Препарати адеметіоніну, таурину та глутатіону зменшували летальність тварин на моделях рабдоміолітичного, гентаміцинового, ішемічно-реперфузійного гострого пошкодження нирок, а при інтоксикації етиленгліколем за критерієм виживаності найбільше подовження тривалості життя та відповідну нефропротекторну активність виявив глутатіон (57,1 \% виживаності тварин через 48 год після введення етиленгліколю проти 100 \% летальності в контролі, $p<0,05)$.

Висновки. Всі досліджені препарати похідних сірковмісних амінокислот (адеметіонін, таурин та глутатіон) виявляють нефропротекторну активність за критерієм виживаності тварин на різних моделях ГПН. Найкращу ефективність при ГПН різного ґенезу демонструє препарат глутатіону, а найменшу - препарат адеметіоніну.

Ключові слова: нефропротекція; гостре пошкодження нирок; виживаність; адеметіонін; таурин; глутатіон 


\section{В. М. Драчук, И. И. Заморский, Т. С. Щудрова, А. М. Горошко}

\section{Влияние препаратов производных серосодержащих аминокислот (адеметионина, таурина и глутатиона) на выживаемость животных при остром повреждении почек различного генеза}

Цель работы - исследование нефропротекторной активности препаратов производных серосодержащих аминокислот (адеметионина, таурина и глутатиона) по интегральному показателю выживаемости животных на разных моделях острого повреждения почек (ОПП).

Материалы и методы. Исследования проводились на 105 нелинейных зрелых белых лабораторных крысах и 35 мышах. Исследуемые препараты: адеметионин - («Гептрал», Abbott SpA, Италия) в дозе 20 мг/кг, препарат глутатиона («ТАД 600», Biomedica Foscama, Италия) в дозе 30 мг/кг, и таурин («Sigma-Aldrich», США) в дозе 100 мг/кг вводили внутрибрюшинно за 3-7 дней до моделирования ОПП. Рабдомиолиз-индуцированное ОПП моделировали внутримышечной инъекцией 50 \% раствора глицерина в дозе 10 мл/кг, токсическое ОПП путем инъекции раствора гентамицина сульфата в дозе 80 мг/кг и подкожного введения мышам этиленгликоля в дозе 10 мл/кг. Ишемическое повреждение почек моделировали под общей анестезией (этаминалом натрия, 40 мг/кг) путем наложения зажимов на обе почечные ножки на период 60 мин с последующей реперфузией в течение 24 часов.

Результаты и их обсуждение. По результатам серии экспериментов по определению влияния исследуемых препаратов производных серосодержащих аминокислот на течение ОПП различного генеза установлено значительное улучшение выживаемости животных. Препараты адеметионина, таурина и глутатиона уменьшали летальность животных на моделях рабдомиолитического, гентамицинового, ишемически-реперфузионного ОПП, а при интоксикации этиленгликолем по критерию выживаемости набольшее увеличение продолжительности жизни и соответствующую нефропротекторную активность проявил глутатион (57,1 \% выживаемости животных через 48 ч после введения этиленгликоля при $100 \%$ летальности в группе контроля, p $<0,05)$.

Выводы. Все исследованные препараты производных серосодержащих аминокислот (адеметионин, таурин и глутатион) проявляют нефропротекторную активность по критерию выживаемости животных при различных моделях ОПП. Наибольшую эффеективность при ОПП различного генеза демонстрирует препарат глутатиона, а наименьшую - препарат адеметионина.

Ключевые слова: нефропротекция; острое повреждение почек; выживаемость; адеметионин; таурин; глутатион

Acute kidney injury (AKI) is a concept that replaced the well-known term "acute kidney failure", but did not change the dynamics of progression of this pathology. The incidence of AKI varies from 1 to $31 \%$, and the mortality rate reaches from 19 to $83 \%[1,2]$. Toxic kidney injury (toxic nephropathy) is usually the result of an accidental domestic food, biological, or industrial professional poisoning. In recent years chemicals that are used in everyday life and industry are of particular importance, therefore, the frequency of toxic nephropathy increases. Despite the widespread introduction of renal replacement therapy, mortality in severe forms of AKI is not characterized by a tendency to decrease [3]. In all cases development of AKI involves some common mechanisms: disturbances of renal (especially cortical) circulation, reduction of glomerular filtration, reduction of reabsorption with total diffusion of the glomerular filtrate through the wall of damaged tubules, compression of the tubules with swollen interstitium, disturbances of the oxidative-reduction processes, in particular activation of free radical oxidation processes against the background of the antioxidant system dysfunction [4].

One of the common types of toxic AKI is ethylene glycol poisoning. Ethylene glycol is a nephrotoxin that quickly causes fatal kidney injury, and its damaging effect on kidneys is due to the toxic effects of its metabolites (oxalic acid). In this case, oxalates of calcium monohydrate are crystallized in the tubular lumen, causing destruction of membrane phospholipids and deve- lopment of acidosis [5-9]. The model of ethylene glycol intoxication is one of the methods of screening research, in which the integral criterion of the nephroprotective effect is survival of animals, which allows reliable verification of the protective effect of nephroprotective compounds.

In order to verify the nephroprotective effect of the derivatives of sulfur-containing amino acids studied (ademetionine, taurine and glutathione) the integral index of animal survival on different models of AKI have been selected. The potential nephroprotective activity of the drugs selected is due to the biological presence of their active components in the form of sulfur-containing amino acids in the body and their biochemical interconversions. Ademethionine is an active metabolite of methionine, has the antioxidant, membranoprotective, cytoprotective, anti-inflammatory and analgesic activity $[10,11]$. Taurine as a sulfur-containing amino acid acts as an osmoregulator of cells, a membranoprotector, a detoxifier, an antioxidant, it provides resynthesis of ATP, exhibits the anti-inflammatory action $[12,13]$. Glutathione is an endogenous tripeptid, an antioxidant, a detoxicant, a membranoprotector, is involved in maintenance of the thiol/ disulphide homeostasis in tissues, and participates in the protein and hydrocarbon metabolism $[14,15]$.

The aim of the study was to compare the nephroprotective effect of sulfur-containing amino acids (ademetionine, taurine and glutathione) on different models of AKI by the integral index of the survival rate of animals. 


\section{Materials and methods}

The series of experiments were performed on 105 nonlinear mature white laboratory rats weighing 130-180 g and 35 mice of both sexes kept in the vivarium at a constant temperature and humidity, with free access to water and food. The rats of each series were divided into 5 groups $(n=7)$ : group I - model pathology, group II animals treated with taurine (Sigma-Aldrich, USA) in the dose of $100 \mathrm{mg} / \mathrm{kg}$, group III - animals treated with ademetionine ("Geptral", Abbott SpA, Italy) in the dose of $20 \mathrm{mg} / \mathrm{kg}$, group IV - animals treated with glutathione (TAD 600, Biomedica Foscama, Italy) in the dose of $30 \mathrm{mg} / \mathrm{kg}$, group $\mathrm{V}$ - animals treated with the reference drug. As a reference drug in rhabdomyolytic AKI lipoflavone (Biolik, Ukraine) in the dose of $8 \mathrm{mg} / \mathrm{kg}$ was chosen; in gentamicin-induced AKI it was canephron (Bionorica CE, Germany) in the dose of $27 \mathrm{mg} / \mathrm{kg}$; in ischemic-reperfusion and toxic ethylene glycol AKI it was mexidol (Pharmasoft, RF) in the dose of $100 \mathrm{mg} / \mathrm{kg}$. All drugs studied (except for canephron, which was used intragastrally) were administered intraperitoneally 3-7 days prior to AKI simulation. The choice of reference drugs in different models of AKI is determined by the evidence base of their nephroprotective potential [16-18].

Rhabdomyolytic AKI in rats was induced by intramuscular administration of $50 \%$ glycerol solution in the dose of $8 \mathrm{ml} / \mathrm{kg}$ in the muscles of the hind legs. In $40 \mathrm{~min}$ after administration of glycerol the animals were given the drugs under study. Gentamicin nephropathy was reproduced by intramuscular administration of $4 \%$ gentamicin sulfate solution (Galychpharm, Ukraine) in the dose of $80 \mathrm{mg} / \mathrm{kg}$ once a day for 6 days; the drugs studied were administered $40 \mathrm{~min}$ after the gentamicin injection. Ischemic-reperfusion AKI was modeled by clamping of both kidney pedicles for $60 \mathrm{~min}$ after the middle laparotomy under general anesthesia (ethaminal sodium, $40 \mathrm{mg} / \mathrm{kg}$ ) followed by reperfusion for $24 \mathrm{~h}$. Toxic ethylene glycol
AKI was caused by a single subcutaneous injection of ethylene glycol in the dose of $10 \mathrm{ml} / \mathrm{kg}$ [19]. The statistical evaluation of the effect was carried out using the Fisher's angle transformation criterion. The critical level of significance was accepted at $p<0.05$. The studies were conducted in accordance with the provisions of the "European Convention for the Protection of Vertebrate Animals used for Experimental and Other Scientific Purposes"[20].

\section{Results and discussion}

The research results of the animal survival in different models of AKI with administration of derivatives of sulfur-containing amino acids and the reference drugs are given in Table. In the group of animals with ethylene glycol AKI the highest mortality was observed: survival of mice was $14.3 \%$ in $12 \mathrm{~h}$, and in $24 \mathrm{~h}$ it was $0 \%$. The weakest protective effect in conditions of ethylene glycol AKI was shown by ademetionine: the survival rate in $12 \mathrm{~h}$ was $28.6 \%(\mathrm{p}>0.05)$, in 2 days all the animals died.

When taurine was used, an improvement in animal survival compared to the model pathology group was observed only during the first day $-42.8 \%$; however, on day 5 all animals died. Glutathione showed the highest efficacy in ethylene glycol AKI: under its effect a significant increase in the survival rate was seen throughout the observation period, which exceeded the protective effect of the reference drug mexidol.

In rhabdomyolytic kidney injury the mortality of animals was $28.6 \%$. The use of the drugs studied showed a tendency to decrease the mortality rate; moreover, there was $100 \%$ survival of the animals in taurine and glutathione groups, it corresponded to the effect of the reference drug lipoflavone; when using ademetionine the survival rate was $85.7 \%$ of animals $(\mathrm{p}>0.05)$.

The predictable high mortality rate was observed among animals with gentamicin nephropathy reaching

Table

The effect of derivatives of sulfur-containing amino acids (ademetionine, taurine and glutathione) on survival of animals with acute kidney injury of various genesis

\begin{tabular}{|c|c|c|c|c|c|c|c|}
\hline $\begin{array}{l}\text { Group of } \\
\text { animals }\end{array}$ & \begin{tabular}{|c} 
Model \\
pathology \\
(AKI)
\end{tabular} & $\begin{array}{c}\text { AKI + } \\
\text { Ademetionine } \\
(20 \mathrm{mg} / \mathrm{kg})\end{array}$ & $\begin{array}{r}\text { AKI + Taurine } \\
(100 \mathrm{mg} / \mathrm{kg})\end{array}$ & $\begin{array}{c}\text { AKI + } \\
\text { Glutathione } \\
\text { (30 mg/kg) }\end{array}$ & $\begin{array}{c}\text { AKI + Mexidol } \\
(100 \mathrm{mg} / \mathrm{kg})\end{array}$ & $\begin{array}{c}\text { AKI + } \\
\text { Lipoflavone } \\
\text { (296 mg/kg) }\end{array}$ & $\begin{array}{c}\text { AKI + } \\
\text { Canephron } \\
(27 \mathrm{mg} / \mathrm{kg}) \\
\end{array}$ \\
\hline \multicolumn{8}{|c|}{ Ethylene glycol AKI $(\%, n=7)$} \\
\hline $12 \mathrm{~h}$ & 14.3 & 28.6 & $57.1^{*}$ & $71.4^{*}$ & $57.1^{*}$ & $u / s$ & $u / s$ \\
\hline $24 \mathrm{~h}$ & 0 & 14.3 & $42.8^{*}$ & $71.4^{*}$ & $42.8^{*}$ & $u / s$ & $u / s$ \\
\hline $48 \mathrm{~h}$ & 0 & 0 & 14.3 & $57.1^{*}$ & 14.3 & $\mathrm{u} / \mathrm{s}$ & $\mathrm{u} / \mathrm{s}$ \\
\hline 3 day & 0 & 0 & 14.3 & $42.8^{*}$ & 14.3 & $\mathrm{u} / \mathrm{s}$ & $\mathrm{u} / \mathrm{s}$ \\
\hline 5 day & 0 & 0 & 0 & $28.6^{*}$ & 0 & $\mathrm{u} / \mathrm{s}$ & $\mathrm{u} / \mathrm{s}$ \\
\hline \multicolumn{8}{|c|}{ Rhabdomyolytic AKI $(\%, n=7)$} \\
\hline $24 \mathrm{~h}$ & 71.4 & 85.7 & $100^{*}$ & $100^{*}$ & $u / s$ & $100^{*}$ & $\mathrm{u} / \mathrm{s}$ \\
\hline \multicolumn{8}{|c|}{ Gentamicin nephropathy $(\%, \mathrm{n}=7)$} \\
\hline 7 day & 57.1 & 71.4 & $85.7^{*}$ & $85.7^{*}$ & $u / s$ & $u / s$ & 71.4 \\
\hline \multicolumn{8}{|c|}{ Ischemia-reperfusion AKI $(\%, \mathrm{n}=7)$} \\
\hline $24 \mathrm{~h}$ & 71.4 & 71.4 & $85.7^{*}$ & $100^{*}$ & $100^{*}$ & $\mathrm{u} / \mathrm{s}$ & $\mathrm{u} / \mathrm{s}$ \\
\hline
\end{tabular}


$42.9 \%$, while the use of drugs reduced the percentage of dead animals with gentamicin nephropathy. The results of the experiment confirm that the effectiveness of ademetionine and the reference drug canephron was lower than the effect of taurine and glutathione, which provided the $85.7 \%$ survival of the experimental animals.

A decrease in the survival of rats to $71.4 \%$ occurred in ischemic-reperfusion AKI. Among the drugs studied only glutathione and mexidol completely prevented the death of animals although the use of taurine and ademetionine also showed a tendency to reduce the mortality of rats since the survival rate after their administration was $87.5 \%$ and $71.4 \%$, respectively.

Therefore, the reduction in mortality of the experimental animals under conditions of AKI of different genesis proves the nephroprotective activity of derivatives of sulfur-containing amino acids, which according to this criterion can be placed in the following order from the maximum to the minimal effect: glutathione taurine - ademetionine.

Thus, according to the results of the study all the simulated forms of AKI were accompanied by the death of a part of the animals, moreover, the expected highest mortality rate in animals was observed in ethylene glycol intoxication. The best protective effect was observed when taking glutathione, as evidenced by $57.1 \%$ survival of mice in 2 days of ethylene glycol AKI development, $100 \%$ survival of rats in rhabdomyolytic and ischemia-reperfusion AKI, and $85.7 \%$ of the animal survival in gentamicin nephropathy. Under the effect of taurine there was a tendency towards improved survival of rats in all AKI models and prolonged life expectancy in ethylene glycol intoxication. The use of ademetionine was the least effective as demonstrated by the highest mortality of mice during the first $12 \mathrm{~h}$ after the simulation of ethylene glycol AKI (71.4\%) and the lowest survival rate in other models of AKI.

\section{CONCLUSIONS}

1. All derivatives of sulfur-containing amino acids studied (ademetionine, taurine and glutathione) exhibit the nephroprotective activity by the criterion of survival of animals on various models of AKI.

2. Glutathione demonstrates the best survival of animals with acute kidney injury of various genesis, while ademetionine has the lowest survival.

Conflict of Interests: authors have no conflict of interests to declare.

\section{REFERENCES}

1. Diagnosis, epidemiology and outcomes of acute kidney injury / S. S. Waikar, K. D. Lin, J. M. Chertow et al. // Soc. Nephrol. - 2008. № 3 (3). - P. 844-861. https://doi.org/10.2215/cjn.05191107

2. Острое повреждение почек : современный взгляд на проблему / Ж. Д. Семидоцкая, И. А. Чернякова, Е. Н. Пионова и др. // Східноєвропейський журн. внутрішньої та сімейної медицини. - 2017. - № 1. - С. 10-16. https://doi.org/10.15407/internalmed2017.01.010

3. Koza, Ya. J. Acute kidney injury : current concepts and new insights / Ya. Koza J. // Inj. Violence Res. - 2016. - № 8 (1). - P. 58-62. https://doi.org/10.5249/jivr.v8i1.610

4. Diagnosis, evaluation, and management of acute kidney injury : a KDIGO summary (Part 1). Crit Care / J. A. Kellum, N. Lameire, for the KDIGO AKI Guideline Work Group. - 2013. - № 17 (1). - P. 204. https://doi.org/10.1186/cc11454

5. A Case of Ethylene Glycol intoxication with Acute Renal Injury: Successful Recovery by Fomepizole and Renal Replacement Therapy / H. S. Chang, J. B. Hong, R. H. Young et al. // Electrolyte Blood Press. - 2017. - № 15 (2). - P. 47-51. https://doi.org/10.5049/ ebp.2017.15.2.47

6. Ethylene glycol toxicity associated with ischemia, perforation, and colonic oxalate crystal deposition / T. B. Gardner, H. L. Manning, A. P. Beelen et al. // J. Clin. Gastroenterol. - 2004. - № 38. - P. 435-439.

7. Autonomic Dysfunction as a Delayed Sequelae of Acute Ethylene Glycol Ingestion / S. S. Rahman, S. Kadakia, L. Balsam et al. // Med. Toxicol. - 2012. - № 8. - P. 124-129. https://doi.org/10.1007/s13181-011-0195-x

8. Hanouneh, M. Calcium Oxalate Crystals in Ethylene Glycol Toxicity / M. Hanouneh, T. K. Chen // New Engl. J. Med. - 2017. - № 377. - P. 1467. https://doi.org/10.1056/nejmicm1704369

9. Prolonged renal failure in the course of atypical ethylene glycol intoxication / T. Liberek, J. Śliwarska, K. Czurak et al. // Acta Biochimica Polonica. - 2013. - № 4 (60). - P. 661-663.

10. Звягинцева, Т. Д. Роль адеметионина в развитии и прогрессировании хронических заболеваний печени / Т. Д. Звягинцева, А. И. Чернобай, С. В. Глущенко // Укр. мед. часопис. - 2014. - № 3 (101). - С. 56-59.

11. Anstee, Q. M. S-adenosylmethionine (SAMe) therapy in liver disease: a review of current evidence and clinical utility / Q. M. Anstee, C. P. Day // J. Hepatol. - 2012. - № 57. - P. 1097-1109. https://doi.org/10.1016/j.jhep.2012.04.041

12. Остапів, Р. Д. Вплив таурину на фізіологічні показники щурів / Р. Д. Остапів, О. С. Кисців, В. В. Манько // Вісник Львів. ун-ту. Сер. Біол. - 2015. - № 69. - С. 247-255.

13. Role of ROS production and turnover in the antioxidant activity of taurine / K. Shimada, C. J. Jong, K. Takahashi, S. W. Schaffer// Adv. Exp. Med. Biol. - 2015. - № 803. - P. 581-596. https://doi.org/10.1007/978-3-319-15126-7 47

14. Role of Glutathione in Cancer Progression and Chemoresistanc / N. Traverso, R. Ricciarelli, M. Nitti et al. // Oxid. Med. Cell Longev. 2013. - Vol. 2013. - P. 1-10. https://doi.org/10.1155/2013/972913

15. Салига, H. О. Активність глутатіонової системи антиоксидантного захисту в щурів за дії L-глутамінової кислоти / Н. O. Салига // Укр. біохім. журн. - 2013. - № 85 (4). - С. 40-47.

16. Горошко, О. М. Лікувальна ефективність одноразового введення ліпосомального препарату кверцетину «Ліпофлавон» при експериментальній гострій нирковій недостатності / О. М. Горошко, І. І. Заморський // Вісник фармації. - 2008. - № 1 (53). - С. 67-71.

17. Мартынюк, Л. П. Влияние растительного препарата Канефрон Н на течение диабетической нефропатии у пациентов с сахарным диабетом 2-го типа: результаты сравнительного когортного исследования / Л. П. Мартынюк, О. А. Ружицкая, Е. С. Мартынюк // Почки. - 2015. - № 1. - С. 24-32.

18. Пат. 28140 Україна, МПК (2006) А 61 К 31/4425. Застосування мексидолу як нефропротекторного засобу / Аракелян Н. Г., Штриголь С. Ю. ; заявник та патентовласник Національний фармацевтичний університет. u200708435; заявл.: 23.07.2007; опубл.: 26.11.2007. - Бюл. № 19. - 4 с. 
19. Методи експериментального моделювання ураження нирок при фармакологічних дослідженнях: метод. рек. ДФЦ України / С. Ю. Штриголь, В. М. Лісовий, І. А. Зупанець та ін. - К., 2009. - С. 9-10.

20. Directive 2010/63/EU of the European Parliament and of the Council on the protection of animals used for scientific purposes // Official J. of the Eur. Union. - 2010. - Vol. 53, Issue 276. - P. 33-80.

\section{REFERENCES}

1. Waikar, S. S., Liu, K. D., \& Chertow, G. M. (2008). Diagnosis, Epidemiology and Outcomes of Acute Kidney Injury. Clinical Journal of the American Society of Nephrology, 3 (3), 844-861. https://doi.org/10.2215/cjn.05191107

2. Semidotska, Z. D., Chernyakova, I. A., Pionova, O. M., ... Tryfonova, N. S. (2017). Acute kidney injury: modern view of problem. Shidnoevropejskij Zurnal Vnutrisnoi Ta Simejnoi Medicini, 2017 (1), 10-16. https://doi.org/10.15407/internalmed2017.01.010

3. Acute kidney injury: Current concepts and new insights. (2014). Journal of Injury and Violence Research, 8 (1), 58-62. https://doi. org/10.5249/jivr.v8i1.610

4. Kellum, J. A., \& Lameire, N. (2013). Diagnosis, evaluation, and management of acute kidney injury: a KDIGO summary (Part 1). Critical Care, 17 (1), 204. https://doi.org/10.1186/cc11454

5. Song, C. H., Bae, H. J., Ham, Y. R., Na, K. R., Lee, K. W., \& Choi, D. E. (2017). A Case of Ethylene Glycol intoxication with Acute Renal Injury: Successful Recovery by Fomepizole and Renal Replacement Therapy. Electrolytes \& Blood Pressure, 15 (2), 47 . https:// doi.org/10.5049/ebp.2017.15.2.47

6. Gardner, T. B., Manning, H. L., Beelen, A. P., Cimis, R. J., Cates, J. M., Lewis, L. D. (2004). Ethylene glycol toxicity associated with ischemia, perforation, and colonic oxalate crystal deposition. J. Clin. Gastroenterol, 38, 435-439.

7. Rahman, S. S., Kadakia, S., Balsam, L., \& Rubinstein, S. (2011). Autonomic Dysfunction as a Delayed Sequelae of Acute Ethylene Glycol Ingestion. Journal of Medical Toxicology, 8 (2), 124-129. https://doi.org/10.1007/s13181-011-0195-x

8. Hanouneh, M., \& Chen, T. K. (2017). Calcium Oxalate Crystals in Ethylene Glycol Toxicity. New England Journal of Medicine, 377 (15), 1467. https://doi.org/10.1056/nejmicm1704369

9. Liberek, T., Śliwarska, J., Czurak, K., Perkowska-Ptasińska, A., Weber, E., Rutkowski, B. (2013). Prolonged renal failure in the course of atypical ethylene glycol intoxication. Acta Biochimica Polonica, 4 (60), 661-663.

10. Zviahyntseva, T. D., Chernobai, A. Y., Hlushchenko, S. V. (2014). Ukrainskyi medychnyi chasopys, 3 (101), 56-59.

11. Anstee, Q. M., \& Day, C. P. (2012). S-adenosylmethionine (SAMe) therapy in liver disease: A review of current evidence and clinical utility. Journal of Hepatology, 57 (5), 1097-1109. https://doi.org/10.1016/j.jhep.2012.04.041

12. Ostapiv, R. D., Kystsiv, O. S., Manko, V. V. (2015). Visnyk Lvivskoho universytetu. Seriia Biolohichna, 69, $247-255$.

13. Shimada, K., Jong, C. J., Takahashi, K., \& Schaffer, S. W. (2015). Role of ROS Production and Turnover in the Antioxidant Activity of Taurine. Advances in Experimental Medicine and Biology, 581-596. https://doi.org/10.1007/978-3-319-15126-7_47

14. Traverso, N., Ricciarelli, R., Nitti, M., Marengo, B., Furfaro, A. L., Pronzato, M. A., ... Domenicotti, C. (2013). Role of Glutathione in Cancer Progression and Chemoresistance. Oxidative Medicine and Cellular Longevity, 2013, 1-10. https://doi.org/10.1155/2013/972913

15. Salyha, N. O. (2013). Ukraïns'kij biofarmacevtičnij žurnal, 85 (4), 40-47.

16. Horoshko, O. M., Zamorskyi, I. I. (2008). Visnik farmaciï, 1 (53), 67-71.

17. Martynjuk, L. P., Ruzhickaja, O. A., Martynjuk, E. S. (2015). Pochki, 1, 24-32.

18. Arakelian, N. H., Shtryhol, S. Yu. (2006). Ukraine. Patent No 28140. Patent and Trademark Office.

19. Shtryhol, S. Yu., Lisovyi, V. M., Zupanets, I. A. (2009). Metody eksperymentalnoho modeliuvannia urazhennia nyrok pry farmakolohichnykh doslidzhenniakh: Metodychni rekomendatsii DFTs Ukrainy. Kyiv, 9-10.

20. Directive 2010/63/EU of the European Parliament and of the Council on the protection of animals used for scientific purposes. (2010). Official Journal of the European Union, 53 (276), 33-80.

\section{Information on authors:}

Zamorskii I. I., Doctor of Medicine (Dr. habil.), professor, head of the Pharmacology Department, Higher State Educational Establishment of Ukraine "Bukovinian State Medical University". E-mail: igor.zamorskii@gmail.com. ORCID: http://orcid.org/0000-0003-0947-6729

Drachuk V. M., teaching assistant of the Pharmacology Department, Higher State Educational Establishment of Ukraine "Bukovinian State Medical University".

E-mail: vira.drachuck2017@gmail.com. ORCID: http://orcid.org/ 0000-0003-3208-7609

Shchudrova T. S. Candidate of Medicine (Ph.D.), associate professor of the Pharmacology Department, Higher State Educational Establishment of Ukraine

"Bukovinian State Medical University". E-mail: tshchudrova@gmail.com. ORCID: http://orcid.org/0000-0003-4186-2013

Goroshko O. M., Candidate of Pharmacy (Ph.D.), associate professor of the Pharmacy Department, Higher State Educational Establishment of Ukraine

"Bukovinian State Medical University”. E-mail: gorolesya@ukr.net. ORCID: http://orcid.org/0000-0002-1341-3010

Інформація про авторів:

Заморський І. І., д-р мед. наук, професор, завідувач кафедри фармакології, Вищий державний медичний університет України «Буковинський державний медичний університет». E-mail: igor.zamorskii@gmail.com. ORCID: http://orcid.org/0000-0003-0947-6729

Драчук В. М., асистент кафедри фармакології, Вищий державний медичний університет України «Буковинський державний медичний університет». E-mail: vira.drachuck2017@gmail.com. ORCID: http://orcid.org/ 0000-0003-3208-7609

Щудрова Т .С., канд. мед. наук, доцент кафедри фармакології, Вищий державний медичний університет України «Буковинський державний медичний університет». E-mail: tshchudrova@gmail.com. ORCID: http://orcid.org/0000-0003-4186-2013

Горошко О. М., канд. фарм. наук, доцент кафедри фармації, Вищий державний медичний університет України «Буковинський державний медичний університет». E-mail: gorolesya@ukr.net. ORCID: http://orcid.org/0000-0002-1341-3010.

Информация об авторах:

Заморский И. И., д-р мед. наук, профессор, заведующий кафедрой фармакологии, Высшее государственное учебное заведение Украины «Буковинский государственный медицинский университет». E-mail: igor.zamorskii@gmail.com. ORCID: http://orcid.org/0000-0003-0947-6729

Драчук В. М., ассистент кафедры фармакологии, Высшее государственное учебное заведение Украины «Буковинский государственный медицинский университет». E-mail: vira.drachuck2017@gmail.com. ORCID: http://orcid.org/ 0000-0003-3208-7609

Щудрова Т. С., канд. мед. наук, доцент кафедры фармакологии, Высшее государственное учебное заведение Украины «Буковинский государственный медицинский университет». E-mail: tshchudrova@gmail.com. ORCID: http://orcid.org/0000-0003-4186-2013

Горошко А. М., канд. фарм. наук, доцент кафедры фармации, Высшее государственное учебное заведение Украины «Буковинский государственный медицинский университет». E-mail: gorolesya@ukr.net. ORCID: http://orcid.org/0000-0002-1341-3010 